\title{
Safety and tolerability of autologous bone marrow mesenchymal stromal cells in ADPKD patients
}

Atieh Makhlough ${ }^{1 \dagger}$, Soroosh Shekarchian ${ }^{2 \dagger}$, Reza Moghadasali ${ }^{2,3}$, Behzad Einollahi ${ }^{4}$, Seyedeh Esmat Hosseini ${ }^{2}$, Neda Jaroughi ${ }^{2}$, Tina Bolurieh ${ }^{2}$, Hossein Baharvand ${ }^{2,3}$ and Nasser Aghdami ${ }^{2 *}$

\begin{abstract}
Background: Autosomal dominant polycystic kidney disease (ADPKD) is a genetic ciliopathy disease characterized by progressive formation and enlargement of cysts in multiple organs. The kidneys are particularly affected and patients may eventually develop end-stage renal disease (ESRD). We hypothesize that bone marrow mesenchymal stromal cells (BMMSCs) are renotropic and may improve kidney function via anti-apoptotic, anti-fibrotic, and anti-inflammatory effects. In this study, we aim to assess the safety and tolerability of a BMMSC infusion in ADPKD patients.

Methods: We performed a single-arm phase I clinical trial with a 12-month follow-up. This study enrolled six eligible ADPKD patients with an estimated glomerular filtration rate (eGFR) of 25-60 ml/min/1.73 m². Patients received autologous cultured BMMSCs $\left(2 \times 10^{6}\right.$ cells $\left./ \mathrm{kg}\right)$ through the cubital vein according to our infusion protocol. We investigated safety issues and kidney function during the follow-up visits, and compared the findings to baseline and 1 year prior to the intervention.

Results: There were no patients lost to follow-up. We observed no cell-related adverse events (AE) and serious adverse events (SAE) after 12 months of follow-up. The mean eGFR value of $33.8 \pm 5.3 \mathrm{ml} / \mathrm{min} / 1.73 \mathrm{~m}^{2} 1$ year before cell infusion declined to $26.7 \pm 3.1 \mathrm{ml} / \mathrm{min} / 1.73 \mathrm{~m}^{2}$ at baseline $(P=0.03)$ and $25.8 \pm 6.2 \mathrm{ml} / \mathrm{min} / 1.73 \mathrm{~m}^{2}$ at the 12 -month follow-up visit $(P=0.62$ ). The mean serum creatinine (SCr) level of $2 \pm 0.3 \mathrm{mg} / \mathrm{dl} 1$ year before the infusion increased to $2.5 \pm 0.4 \mathrm{mg} / \mathrm{dl}$ at baseline $(P=0.04)$ and $2.5 \pm 0.6 \mathrm{mg} / \mathrm{dl}$ at the 12-month follow-up $(P=0.96)$. This indicated significant changes between the differences of these two periods ( 12 months before infusion to baseline, and 12 months after infusion to baseline) in $\mathrm{SCr}(P=0.05)$, but not eGFR $(P=0.09)$.
\end{abstract}

Conclusions: This trial demonstrated the safety and tolerability of an intravenous transplantation of autologous BMMSCs. BMMSC efficacy in ADPKD patients should be investigated in a randomized placebo-controlled trial with a larger population, which we intend to perform.

Trial registration: ClinicalTrials.gov, NCT02166489. Registered on June 14, 2014.

Keywords: Autosomal dominant polycystic kidney disease, Bone marrow mesenchymal stromal cells, Chronic kidney disease

\footnotetext{
* Correspondence: nasser.aghdami@royaninstitute.org

${ }^{\dagger}$ Equal contributors

${ }^{2}$ Department of Regenerative Biomedicine, Cell Science Research Center,

Royan Institute for Stem Cell Biology and Technology, ACECR, Tehran, Iran

Full list of author information is available at the end of the article
} 


\section{Background}

Autosomal dominant polycystic kidney disease (ADPKD) is a genetic ciliopathy disease characterized by progressive formation and enlargement of cysts in multiple organs. The kidneys are particularly affected and patients may eventually progress to end-stage renal disease (ESRD). ADPKD is the most common genetic renal disease [1] that affects approximately 4 to 7 million individuals [2]. Mutations in polycystins 1 and 2 impair homeostasis and intracellular calcium signaling, which subsequently cause cyst formation, inflammation, and fibrosis in the kidneys [3, 4].

Despite recent advances in the identification of ADPKD pathogenesis, current treatments have been unable to completely cure or control disease progression. Tolvaptan, a vasopressin II receptor antagonist (V2RA), is the only drug that has passed a phase III clinical trial. Though it has the ability to reduce progression of height-adjusted total kidney volume (htTKV), it is associated with numerous adverse effects [5].

Transplantation of mesenchymal stromal cells (MSCs) is a recent approach to treat renal disease [6, 7]. MSCs are plastic-adherent cells that must at least express CD73, CD90, and CD105 and lack expression of CD45, CD34, CD14 and human leukocyte antigen (HLA)-DR. They have the potential for in vitro differentiation to osteoblasts, adipocytes, and chondroblasts [8]. Several studies report their ability to treat renal diseases by different mechanisms [9]. Anti-apoptotic [10], anti-fibrotic [11], and anti-inflammatory [12] capabilities of MSCs [7] provide the basis for their administration to control the progression of polycystic kidney disease (PKD). Franchi et al. have reported that transplanted MSCs restored kidney function in a PKD model and improved damaged vasculature of these kidneys [13]. Previously we showed the promising efficacy of transplanted MSCs in experimental models of chronic kidney disease (CKD) and acute kidney injury (AKI) [14-16]. We had indicated that MSC-derived conditioned medium induced renal tubular cell regeneration after nephrotoxicity induction [14], then we showed the bone marrow MSC (BMMSC) lowered serum creatinine ( $\mathrm{SCr}$ ) and urea levels and accelerated regulatory $\mathrm{T}$ cells (Tregs) in a monkey AKI model [15]. In a recent study, our results indicated that MSCs resulted in decreased CKD progression in a monkey model [16]. Carvalhosa et al. reported that cells lining cysts in ADPKD consisted of polycystic CD133+ progenitor [17]. Our unpublished data showed that in vitro co-culture of MSCs and tubular CD133+ progenitor cells from ADPKD patients resulted in reduced cyst formation and proliferation potential.

We hypothesize that MSCs are renotropic. Therefore, this study aims to assess the safety and tolerability of MSC infusion in ADPKD patients.

\section{Methods}

Study design

We performed a single-arm phase I clinical trial at one trial center with a 12-month follow-up period. We investigated safety issues and kidney function during the follow-up visits, and compared the findings to baseline and 1 year prior to intervention. Table 1 shows the study assessment schedule. We evaluated 27 ADPKD patients for potential participation in this trial. We had diagnosed all these patients according to unified imaging diagnostic criteria [18]. Patients were under our observation for at least 1 year prior to study enrollment. Their blood pressures (BP) were well controlled. From these potential participants, we recruited six eligible ADPKD patients who provided written informed consent for study participation. This study enrolled patients from June 2014 to January 2015. All patients have been on a special diet that included decreased salt, protein, and caffeine consumption, and high water intake, recommended by our nutritionist. We strongly recommended that patients keep track and not change their medications, supplements, or make any lifestyle changes. This trial was registered with clinical trial number NCT02166489.

We evaluated both safety and tolerability of the cell infusion according to physical examination, adverse event (AE) assessments, and laboratory changes. Potential efficacy included changes in kidney length (KL) measured by ultrasound imaging, estimated glomerular filtration rate (eGFR) by the modification of diet in renal disease (MDRD) study formula, and glomerular filtration rate (GFR) by diethylenetriaminepentaacetic acid (DTPA) scan.

We abstracted data that pertained to the " 1 year prior to infusion" point from patients' medical files in the clinic. We scheduled patient follow-up visits for clinical and laboratory assessments at specified intervals of 1 , $3,6,9$, and 12 months after the cell infusion.

\section{Enrollment criteria}

Inclusion criteria were: (1) both genders; (2) ADPKD confirmed by sonography imaging or genetic testing; (3) age 18 to 60 years; (4) eGFR $25-60 \mathrm{~mL} / \mathrm{min} / 1.73 \mathrm{~m}^{2}$; (5) ability to understand and willingness to sign a consent form. Exclusion criteria consisted of: (1) pregnancy or breastfeeding; (2) positive history of associated cardiovascular disease; (3) diabetes that required medical intervention; (4) other systemic diseases that involved the kidneys such as cancers, autoimmune diseases, blood diseases, and liver diseases; (5) hospitalization due to illness 2 months prior to study entry; (6) life expectancy less than 2 years; and (7) allergies to the cell culture ingredients. 
Table 1 Assessment schedule

\begin{tabular}{|c|c|c|c|c|c|c|c|c|c|c|}
\hline & SV & BV1 & $\mathrm{V} 1$ & BV2 & V2 & V3 & V4 & V5 & V6 & V7 \\
\hline Day & -56 & -49 & -42 & 0 & 1 & 30 & 90 & 180 & 270 & 360 \\
\hline Time window & NA & $\pm 3 d$ & $\pm 7 d$ & $\pm 1 d$ & $\pm 1 d$ & $\pm 7 d$ & $\pm 7 d$ & $\pm 7 d$ & $\pm 7 d$ & $\pm 7 d$ \\
\hline Informed consent & $x$ & & & & & & & & & \\
\hline Physical examination & $x$ & $x$ & & $x$ & & $x$ & $x$ & $x$ & $x$ & $x$ \\
\hline Vital signs & $x$ & $x$ & $x$ & $x$ & & $x$ & $x$ & $x$ & $x$ & $x$ \\
\hline Medical history & $x$ & & & & & & & & & \\
\hline Laboratory assessments & $x$ & & & $x$ & & $x$ & $x$ & $x$ & $x$ & $x$ \\
\hline $\mathrm{CBC}$ & & & & $x$ & & $x$ & $x$ & $x$ & $x$ & $x$ \\
\hline BG & & & & $x$ & & $x$ & $x$ & $x$ & $x$ & $x$ \\
\hline$N A, K, C a, P$ & & & & $x$ & & $x$ & $x$ & $x$ & $x$ & $x$ \\
\hline BUN & & & & $x$ & & $x$ & $x$ & $x$ & $x$ & $x$ \\
\hline Uric acid & & & & $x$ & & $x$ & $x$ & $x$ & $x$ & $x$ \\
\hline Serum creatinine & $x$ & & & $x$ & & $x$ & $x$ & $x$ & $x$ & $x$ \\
\hline eGFR & $x$ & & & $x$ & & $x$ & $x$ & $x$ & $x$ & $x$ \\
\hline Albumin & & & & $x$ & & & & $x$ & & $x$ \\
\hline TG, Chol, LDL,HDL & & & & $x$ & & $x$ & $x$ & $x$ & $x$ & $x$ \\
\hline FBS & $x$ & & & $x$ & & $x$ & $x$ & $x$ & $x$ & $x$ \\
\hline $\mathrm{HbA1C}$ & $x$ & & & & & & & & & $x$ \\
\hline TSH, PTH & & & & $x$ & & & & & & $x$ \\
\hline ESR, CRP & & & & $x$ & & $x$ & $x$ & $x$ & $x$ & $x$ \\
\hline ALT, ALK-p, AST & & & & $x$ & & $x$ & $x$ & $x$ & $x$ & $x$ \\
\hline Dipstick proteinuria & & & & $x$ & & $x$ & $x$ & $x$ & $x$ & $x$ \\
\hline HIV 1,2, HCV, HBV, HTLV & $x$ & & & & & & & & & \\
\hline Eligibility criteria assessment & $x$ & & & $x$ & & & & & & \\
\hline Kidney sonography & & $x$ & & & & & & & & $x$ \\
\hline Kidney DTPA scan & & $x$ & & & & & & & & $x$ \\
\hline BM harvesting & & & $x$ & & & & & & & \\
\hline MSC infusion & & & & & $x$ & & & & & \\
\hline Follow-up visit & & & & & & $x$ & $x$ & $x$ & $x$ & $x$ \\
\hline $\mathrm{AE}$ assessment ${ }^{\mathrm{a}}$ & & & & & $x$ & $x$ & $x$ & $x$ & $x$ & $x$ \\
\hline SAE assessment ${ }^{a}$ & & & & & $x$ & $x$ & $x$ & $x$ & $x$ & $x$ \\
\hline
\end{tabular}

$S V$ screen visit, $B V 1$ baseline visit before bone marrow aspiration (BMA), $B V 2$ baseline visit before infusion day, $V$ visit, $d$ day, $C B C$ complete blood count, $B U N$ blood urea nitrogen, eGFR estimated glomerular filtration rate, TG triglycerides, Chol cholesterol, $L D L$ low-density lipoprotein, $H D L$ high-density lipoprotein, $F B S$ fasting blood sugar, HbA1c hemoglobin A1c, TSH thyroid-stimulating hormone, PTH parathyroid hormone, ESR erythrocyte sedimentation rate, CRP C-reactive protein, ALT alanine aminotransferase, AIK-p alkaline phosphatase, AST aspartate aminotransferase, HIV human immunodeficiency virus, HCV hepatitis C virus, HBV hepatitis B virus, HTLV human T-lymphotropic virus, DTPA diethylenetriaminepentaacetic acid, BM bone marrow, MSC mesenchymal stromal cell, $A E$ adverse event, SAE serious adverse event

${ }^{\mathrm{a}} \mathrm{AE}$ and SAE were assessed during the follow-up visit and when reported by patients

\section{Primary and secondary endpoints}

Primary endpoints consisted of the numbers, type, and severity of AEs related to the cell infusion. We recorded AEs and serious adverse events (SAE) during follow-up visits and whenever patients reported any symptoms. We recorded the type and grade of AEs according to the Common Terminology Criteria for Adverse Events (CTCAE) version 4.0. We sent these reports to the Data Safety Monitoring Board (DSMB) of the study. Secondary endpoints consisted of changes in eGFR (as an existing surrogate endpoint) [19] from baseline to 12 months after the cell infusion.

\section{Kidney ultrasound imaging and kidney DTPA scan} Additional file 1 lists this information.

Bone marrow aspiration (BMA) procedure, cell preparation, and culture

Once the patients' laboratory viral tests were normal (Additional file 1: Table S1), an oncologist performed a bone marrow aspiration (BMA) under local anesthesia ( $2 \%$ lidocaine solution) and an intravenous sedation that consisted of $0.1 \mathrm{mg} / \mathrm{kg}$ midazolam and 25-50 mg intravenous fentanyl. The BMA was obtained from the posterior superior iliac crest with the patient placed in 
the lateral decubitus position. Samples were placed inside a cold box and sent to the clean room. The oncologist discharged all patients $4 \mathrm{~h}$ after the procedure. We telephoned patients 2 days later to ask about any complications related to the BMA procedure. None of the patients reported any complications. Bone marrow (BM) mononuclear cells were plated at $1 \times 10^{6} \mathrm{cells} / \mathrm{cm}^{2}$ in a $150-\mathrm{cm}^{2}$ culture flask with alpha modified Eagle medium ( $\alpha$-MEM; 22571-020, Gibco BRL, Karlsruhe, Germany) supplemented with $100 \mathrm{IU}$ penicillin and $100 \mathrm{IU}$ streptomycin (15070-063, Gibco), 10\% Hyclone defined fetal bovine serum (FBS; SH30070.03, Thermo Fisher Scientific, Waltham, MA, USA), and 1\% L-glutamine (25030024, Gibco). Phase-contrast microscopy of the BMMSC cultures demonstrated a low heterogeneous population that predominately consisted of long, spindle-shaped cells. For each patient, we characterized the cells for immunophenotypic properties that included surface marker expressions for MSCs - phycoerythrin (PE)-conjugated CD105, CD44, CD73 (Becton Dickinson, Franklin Lakes, NJ, USA) and fluorescein isothiocyanate (FITC)-conjugated CD90 (Dako, Glostrup, Denmark) along with those that were negative for hematopoietic stem cell (HSC) surface markers PE-conjugated CD34 and FITC-conjugated CD45. Negative isotype controls included nonspecific mouse IgG1-FITC/IgG1-PE and IgG2a-FITC that were substituted for the primary antibody. All samples were analyzed by flow cytometry (BD FACS Caliber, BD Biosciences, San Jose, CA, USA) and win-MDI2.9 software. Additional file 2: Figure S1 show MSC characterization of the enrolled patients. The cells were tested for possible microbial contamination prior to infusion. We used quality control tests (QCT) in accordance with the recommendations for cell and tissue therapy promotion and validation tests of the Iranian Health Ministry Pharmacopoeia Commission and the Department of Health and Human Services, Food and Drug Organization (FDO). Tests included the sample microbial test, limulus amebocyte lysate (LAL) gel clot assay, mycoplasma detection, and karyotype analysis.

Passages 1 to 3 of the cultured BMMSCs were washed with phosphate-buffered saline and trypsinized with trypsin/EDTA (0.05\%; 25300-062, Gibco). The cells were diluted in $10 \mathrm{ml}$ of normal saline and loaded into $10 \mathrm{ml}$ sterile syringes. For each patient, we prepared approximately $1-2 \times 10^{6}$ cells $/ \mathrm{kg}$, which were delivered to the institute's operating room in a cold box at a temperature of approximately $4{ }^{\circ} \mathrm{C}$.

\section{Cell infusion}

We infused autologous cultured MSCs $\left(1-2 \times 10^{6} / \mathrm{kg}\right)$ through the cubital vein according to our infusion protocol.

\section{Statistical analysis}

Data are written as mean \pm standard deviation (SD). Following normal distribution of parametric data, we used the paired $t$ test to compare variables at two time points (baseline and 12 months after cell infusion). We compared variables at three time points (12 months before infusion, baseline, and 12 months after infusion) by the repeated measures ANOVA test. A twosided $P$ value of $<0.05$ was considered statistically significant. We used SPSS for statistical analyses (Version 16, SPSS Inc., Chicago, IL, USA).

\section{Results}

\section{Patient characteristics}

All six patients completed the trial. No patients were lost to follow-up. Table 2 lists the patients' characteristics and demographic data at the time of enrollment. Additional file 1: Table S1 shows the cell parameters. All patients' BP was under tight control prior to enrollment. Patients' antihypertensive medications did not change during the trial. There were five patients with children. None of these patients underwent any procedures to prevent the transmission of the disease gene to their children. One patient has not attempted to have any children. None experienced external renal complications due to PKD prior to enrollment. We did not observe any external renal complications from PKD during the 12 months of follow-up. Although one patient had autosomal dominant polycystic liver disease (ADPLD), we did not observe any changes in the size of her liver by ultrasonography at the 12-month follow-up.

\section{Safety and tolerability}

We discharged all patients $2 \mathrm{~h}$ after the cell infusion and observed no AEs during this time. The bone marrow puncture site healed within $72 \mathrm{~h}$ and the intravenous infusion site healed within $24 \mathrm{~h}$ without any related complications. In total, we recorded $1 \mathrm{SAE}$ and 37 AEs during the 12-month follow-up in all patients (Additional file 1: Table S2).

We sent the related AE reports to the DSMB of the trial as scheduled. The DSMB raised the issue that vomiting and dizziness AEs occurred shortly after the DTPA kidney scan in the majority of patients at the baseline and follow-up visits. They recommended that we cancel the DTPA kidney scans for the rest of the trial.

According to DSMB comments, all other AEs were unrelated to the intervention and probably attributed to patients' underlying disease progression or other medical conditions. All AEs resolved spontaneously or by the use of over-the-counter medications. 
Table 2 Patient characteristics and demographic data at the time of enrollment

\begin{tabular}{|c|c|c|c|c|c|c|}
\hline Patient number & 1 & 2 & 3 & 4 & 5 & 6 \\
\hline $\operatorname{Sex}(m / f)$ & $F$ & $M$ & $M$ & $M$ & $\mathrm{~F}$ & $\mathrm{~F}$ \\
\hline Age (years) & 45 & 37 & 39 & 28 & 51 & 54 \\
\hline Race & Caucasian & Caucasian & Caucasian & Caucasian & Caucasian & Caucasian \\
\hline $\begin{array}{l}\text { Educational } \\
\text { level }\end{array}$ & $\begin{array}{l}\text { Graduate } \\
\text { studies }\end{array}$ & $\begin{array}{l}\text { Completed high } \\
\text { school }\end{array}$ & Graduate studies & $\begin{array}{l}\text { Graduate } \\
\text { studies }\end{array}$ & $\begin{array}{l}\text { Completed high } \\
\text { school }\end{array}$ & $\begin{array}{l}\text { Completed } \\
\text { high school }\end{array}$ \\
\hline Marital status & Married & Married & Married & Married & Married & Married \\
\hline $\begin{array}{l}\text { Number of } \\
\text { children }\end{array}$ & 2 & 1 & 2 & 0 & 2 & 2 \\
\hline Employment & $\begin{array}{l}\text { Full-time } \\
\text { employment }\end{array}$ & $\begin{array}{l}\text { Full-time } \\
\text { employment }\end{array}$ & $\begin{array}{l}\text { Part-time } \\
\text { employment }\end{array}$ & $\begin{array}{l}\text { Full-time } \\
\text { employment }\end{array}$ & Retired & Homemaker \\
\hline $\begin{array}{l}\text { Diagnosis } \\
\text { due to }\end{array}$ & Incidental imaging & Screening & Screening & Screening & Screening & Screening \\
\hline BMI $\left(\mathrm{kg} / \mathrm{m}^{2}\right)$ & 29.38 & 26.45 & 26.18 & 35.51 & 24.34 & 23.41 \\
\hline Blood group & $\mathrm{O}+$ & $A^{-}$ & At & $\mathrm{O}+$ & $\mathrm{B}+$ & B+ \\
\hline $\begin{array}{l}\text { BP sitting } \\
\text { position } \\
\text { (mm Hg) }\end{array}$ & $135 / 80$ & $115 / 79$ & $110 / 70$ & $131 / 70$ & $133 / 73$ & $127 / 83$ \\
\hline $\begin{array}{l}\text { eGFR }(\mathrm{ml} / \mathrm{min} / \\
\left.1.73 \mathrm{~m}^{2}\right)\end{array}$ & 25 & 32 & 25 & 25 & 25 & 29 \\
\hline $\begin{array}{l}\text { GFR DTPA } \\
\text { SCAN }\end{array}$ & 23 & 41.6 & 24 & 28 & 26 & 32.83 \\
\hline $\begin{array}{l}\text { Serum creatinine } \\
(\mathrm{mg} / \mathrm{dl})\end{array}$ & 2.3 & 2.3 & 2.8 & 3.0 & 2.5 & 1.9 \\
\hline $\begin{array}{l}\text { Dipstick } \\
\text { proteinuria }\end{array}$ & Trace & $\mathrm{Neg}$ & Trace & Neg & Neg & + \\
\hline \multicolumn{7}{|c|}{ Previous symptoms or complication of ADPKD (yes/no) } \\
\hline Cyst infection & $\mathrm{N}$ & N & N & N & N & N \\
\hline Urinary infection & Y & $\mathrm{N}$ & N & Y & N & N \\
\hline Flank pain & $\mathrm{N}$ & $\mathrm{N}$ & $\mathrm{N}$ & Y & Y & N \\
\hline Macrohematuria & N & N & N & Y & Y & N \\
\hline Other & N & $\mathrm{N}$ & $\mathrm{N}$ & N & N & N \\
\hline \multicolumn{7}{|c|}{ Past medical history (yes/no) } \\
\hline DM & $\mathrm{N}$ & $\mathrm{N}$ & $\mathrm{N}$ & N & N & N \\
\hline HTN & Y & Y & Y & Y & Y & Y \\
\hline ADPLD & $\mathrm{N}$ & $\mathrm{N}$ & $\mathrm{N}$ & N & N & Y \\
\hline Other (name) & $\begin{array}{l}\text { L4, L5 laminectomy, } \\
\text { kidney stone }\end{array}$ & Varicocelectomy & $\begin{array}{l}\text { Low back pain, } \\
\text { kidney stone }\end{array}$ & $\begin{array}{l}\text { Incarcerated } \\
\text { spinal disc, } \\
\text { canal stenosis, } \\
\text { kidney stone, } \\
\text { fatty liver grade I }\end{array}$ & $\begin{array}{l}\text { Hypothyroidism, } \\
\text { kidney stone, C/S } \\
\text { surgery }\end{array}$ & Hysterectomy \\
\hline $\begin{array}{l}\text { Diagnosis of } \\
\text { HTN, age }\end{array}$ & 40 & 32 & 19 & 22 & 36 & 44 \\
\hline $\begin{array}{l}\text { Duration of CKD at } \\
\text { enrollment } \\
\text { (estimation by } \\
\text { month) }\end{array}$ & 62 & 132 & 36 & 14 & 120 & 120 \\
\hline $\begin{array}{l}\text { Smoking history } \\
\text { (yes/no) }\end{array}$ & $\mathrm{N}$ & $\mathrm{N}$ & $\mathrm{N}$ & N & $\mathrm{N}$ & N \\
\hline $\begin{array}{l}\text { Alcohol } \\
\text { consumption } \\
\text { history (yes/no) }\end{array}$ & N & N & N & N & N & N \\
\hline $\begin{array}{l}\text { Family history } \\
\text { of ADPKD (yes/no) }\end{array}$ & $\mathrm{N}$ & Y & Y & Y & Y & Y \\
\hline $\begin{array}{l}\text { Under controlled } \\
\text { diet (yes/no) }\end{array}$ & Y & Y & Y & Y & Y & Y \\
\hline
\end{tabular}


Table 2 Patient characteristics and demographic data at the time of enrollment (Continued)

\begin{tabular}{ll}
\hline Drug list & Metoral $50 \mathrm{mg} /$ \\
(name/dose) & daily calcitrol I daily \\
& PD-poetin each \\
& 10 days
\end{tabular}

$\begin{array}{ll}\text { Gemfibrozil } 300 \mathrm{mg} / \text { daily } & \text { Enalapril } \\ \text { losartan } 25 \mathrm{mg} / \text { daily } & 5 \mathrm{mg} / \text { daily } \\ \text { amlodipine } 5 \mathrm{mg} / \text { daily } & \text { losartan } \\ \text { allopurinol } 100 \mathrm{mg} / \text { daily } & 25 \mathrm{mg} / \text { daily } \\ \text { calcium I daily }\end{array}$

$\begin{array}{lll}\text { Losartan } 25 \mathrm{mg} / \text { daily atenolol } & \text { Losartan } 25 \mathrm{mg} 1 / 2 \text { daily } & \text { Losartan } 50 \mathrm{mg} \\ 50 \mathrm{mg} / \text { daily diltiazem } 60 \mathrm{mg} / \text { daily } & \text { atorvastatin } 20 \mathrm{mg} / \text { daily } & \text { bid amilodipine } \\ \text { prazocin } 5 \mathrm{mg} / \text { daily allopurinol } & \text { allopurinol } 100 \mathrm{mg} 1 / 2 \text { daily } & 50 \mathrm{mg} / \text { daily } \\ 100 \mathrm{mg} / \text { daily, nephrovit I daily, } & \text { levothyroxine } 1 / 2 \text { daily } & \text { allopurinol } \\ \text { vit } \mathrm{D}_{3} \text { I biweekly } & \text { calcitrol in } 5 \text { days of week } & 100 \mathrm{mg} / \text { daily }\end{array}$

$B M I$ body mass index, BP blood pressure, eGFR estimated glomerular filtration rate, DTPA diethylenetriaminepentaacetic acid, $A D P K D$ autosomal dominant polycystic kidney disease, DM diabetes mellitus, HTN hypertension, ADPLD autosomal dominant polycystic liver disease, CKD chronic kidney disease, NA not applicable, $N$ no, $Y$ yes

${ }^{a}$ Neg: 0 mg/dl; Trace: $15-30 \mathrm{mg} / \mathrm{dl}$; +: 30-100 mg/dl; ++: $100-300$ mg/d; +++: 300-1000 mg/dl; ++++: >1000 mg/dl

b Under controlled diet is defined as: no: on normal diet; yes: patients have been under the recommendation of nutritionist by taking low protein, low salt diet, with low caffeine and high intake of water

One patient experienced an SAE. Patient number 3 who had a positive history for low back pain took a single dose of a celecoxib tablet $(200 \mathrm{mg})$ and one acetaminophen tablet $(500 \mathrm{mg})$ due to severe back pain 3 weeks after his cell infusion. His blood urea nitrogen (BUN) and SCr levels elevated $24 \mathrm{~h}$ after celecoxib and acetaminophen. We advised him against using these types of medications. Instead, we prescribed physiotherapy for pain relief. After 1 week, his BUN and SCr values returned to previous levels. We referred him to the orthopedic surgeon who performed a lumbosacral magnetic resonance imaging (MRI) scan without contrast. According to the MRI report, the patient had L4/L5 disc demyelination and a central disc protrusion with significant canal and left foraminal stenosis. He underwent surgery 1 week later. After surgery, his pain reduced and cleared completely within 10 days.

\section{Primary endpoint}

We did not detect any SAEs or AEs related to the cell infusion in any of the patients during the 12-month follow-up. The results showed no significant differences in laboratory parameters, which we evaluated for safety issues after 1, 3, 6, 9 (Additional file 1: Table S3) and 12 months compared to baseline (Table 3).

\section{Secondary endpoint}

The single-dose autologous MSC infusion did not induce any significant changes in eGFR, nor reductions in $\mathrm{SCr}$ at 12 months compared to baseline in all patients (Table 4).

\section{eGFR, sCr, and blood pressure (BP)}

Patients had a mean eGFR value of $33.8 \pm 5.3 \mathrm{ml} / \mathrm{min} /$ $1.73 \mathrm{~m}^{2} 1$ year before the cell infusion, which declined to $26.7 \pm 3.1 \mathrm{ml} / \mathrm{min} / 1.73 \mathrm{~m}^{2}$ at baseline $(P=0.03)$ and 25.8 $\pm 6.2 \mathrm{ml} / \mathrm{min} / 1.73 \mathrm{~m}^{2}$ at the 12 -month visit $(P=0.62)$. Figure 1 shows the patients' eGFR changes. The mean $\mathrm{SCr}$ level of $2 \pm 0.30 \mathrm{mg} / \mathrm{dl}$ within the same period increased to $2.5 \pm 0.4 \mathrm{mg} / \mathrm{dl}$ at baseline $(P=0.04)$ and $2.5 \pm 0.6 \mathrm{mg} / \mathrm{dl}$ at the 12-month follow-up $(P=0.96)$. There was a significant change between the differences of these two periods $(-12$, baseline and +12 , baseline) in $\mathrm{SCr}(P=0.05)$ but not in eGFR $(P=0.09$; Table 4$)$.
Systolic $(P=0.55)$ and diastolic $(P=0.43)$ BP did not significantly change 12 months after the cell infusion (Table 4). We observed no significant changes in renal function parameters and BP during the year after intervention (Additional file 1: Table S4).

\section{Kidney length (KL)}

There was a slight increase in the median left $\mathrm{KL}$ at baseline $(18.3 \pm 2.4 \mathrm{~cm})$ to 12 months after the cell infusion $(18.7 \pm 2.6 \mathrm{~cm} ; P=0.06)$. The median right $\mathrm{KL}$ at baseline was $19.1 \pm 2 \mathrm{~cm}$ which increased slightly to $19.5 \pm 2 \mathrm{~cm}$ at 12 months $(P=0.13$; Table 4$)$.

\section{Discussion}

To the best of our knowledge, this is the first clinical trial that has shown the safety and tolerability of a single BMMSC intravenous infusion in ADPKD patients.

However, the mean eGFR level noticeably decreased from 1 year before intervention to baseline $(P=0.03)$. We observed a slight, nonsignificant decrease for eGFR at 12-month follow-up that could not be considered exactly due to the intervention.

We observed enlargement of both kidneys in all patients at 12 months after the cell infusion that was probably due to usual cyst growth. We used KL to evaluate disease progression and, to some extent, represent the size of the kidney $[20,21]$. However, $\mathrm{KL}$ is not as appropriate as HtTKV as proposed by the Consortium for Radiologic Imaging Studies of Polycystic Kidney Disease (CRISP) [22].

The HALT study showed a crucial role for hypertension (HTN) control in management of ADPKD [23]. Accordingly, we tightly controlled HTN in our patients prior to their enrollment. This did not change during the follow-up period.

Franchi et al. performed the only preclinical study that used allogeneic MSCs in a PKD rat model. They showed the beneficial effect of a single intravenous infusion for improvements in systolic HTN and fibrosis. Although the infusion did not affect cyst size and number, it had a significant improvement on cortical and parenchymal vasculature density, which resulted in better tubular function and improvements in creatinine clearance seen in the intervention group in the autosomal recessive 
Table 3 Laboratory parameters at baseline and 12-month follow-up

\begin{tabular}{|c|c|c|c|c|c|}
\hline Patient parameters & Normal range & Baseline (Mean \pm SD) & 12-month (Mean $\pm S D)$ & Difference (Mean \pm SD) & $P$ value (Paired $t$ test) \\
\hline Leukocytes (/ul) & $4000-10000$ & $5700 \pm 885.4$ & $6468.3 \pm 2153.2$ & $768.3 \pm 1406.9$ & 0.24 \\
\hline Hemoglobin $(\mathrm{g} / \mathrm{dl})$ & $12-16$ & $12.8 \pm 1.7$ & $13 \pm 1.2$ & $0.2 \pm 0.8$ & 0.55 \\
\hline HCT (\%) & $38-47$ & $37.4 \pm 3.8$ & $39.5 \pm 3.4$ & $2.1 \pm 2.9$ & 0.15 \\
\hline $\mathrm{MCV}(\mathrm{fl})$ & $80-96$ & $88.8 \pm 9.4$ & $89.5 \pm 3.3$ & $0.7 \pm 7.8$ & 0.82 \\
\hline Platelets $\left({ }^{*} 10^{3} / \mathrm{ul}\right)$ & $150-450$ & $211.7 \pm 56.8$ & $187.3 \pm 42$ & $-24.3 \pm 46$ & 0.25 \\
\hline $\mathrm{FBS}(\mathrm{mg} / \mathrm{dl})$ & $60-105$ & $96.8 \pm 10$ & $87.4 \pm 11.9$ & $-6.2 \pm 7.2$ & 0.13 \\
\hline HbA1c (\%) & $4-6$ & $5.2 \pm 0.3$ & $5.1 \pm 0.40$ & $0 \pm 0.1$ & 0.3 \\
\hline Sodium (mEq/l) & $134-148$ & $141.8 \pm 1.9$ & $141.3 \pm 2$ & $-0.5 \pm 1.2$ & 0.36 \\
\hline Potassium (mEq/l) & $3.5-5.5$ & $4.4 \pm 0.5$ & $4.3 \pm 0.5$ & $-0.1 \pm 0.4$ & 0.41 \\
\hline Calcium (mg/dl) & $8.6-10$ & $9.3 \pm 0.6$ & $9.4 \pm 0.3$ & $0 \pm 0.8$ & 0.79 \\
\hline Phosphorus (mg/dl) & $2.6-4.5$ & $3.7 \pm 0.6$ & $3.7 \pm 0.5$ & $0 \pm 0.5$ & 0.89 \\
\hline TSH (MIU/ml) & $0.2-5.0$ & $2.3 \pm 1.1$ & $2.4 \pm 1.3$ & $0.1 \pm 1.7$ & 0.86 \\
\hline PTH (pg/ml) & $15-65$ & $140.3 \pm 71$ & $112 \pm 48.3$ & $-29.2 \pm 55.2$ & 0.25 \\
\hline ESR $1 \mathrm{~h}(\mathrm{~mm} / \mathrm{h})$ & $3-20$ & $22.2 \pm 18.8$ & $15.5 \pm 10.3$ & $-6.7 \pm 9.9$ & 0.16 \\
\hline CRP $(\mathrm{mg} / \mathrm{l})$ & $0-10$ & $5.1 \pm 8.7$ & $0.3 \pm 0.9$ & $-4.7 \pm 8.5$ & 0.23 \\
\hline Albumin (g/dl) & $3.5-5.2$ & $4.3 \pm 0.3$ & $4.4 \pm 0.5$ & $0.1 \pm 0.6$ & 0.68 \\
\hline Uric acid (mg/l) & $2.6-6$ & $6.5 \pm 2.1$ & $7.2 \pm 1.3$ & $0.7 \pm 1.7$ & 0.38 \\
\hline $\operatorname{ALT}(U / I)$ & $0-40$ & $24.3 \pm 9.8$ & $19.3 \pm 6.6$ & $-5.0 \pm 11.5$ & 0.34 \\
\hline AST (U/l) & $0-31$ & $29.7 \pm 18.5$ & $20.5 \pm 5.8$ & $-9.1 \pm 17.4$ & 0.25 \\
\hline Alkaline phosphatase (U/l) & $0-240$ & $231.2 \pm 62.5$ & $155.8 \pm 53.8$ & $-75.3 \pm 83.9$ & 0.07 \\
\hline Total cholesterol (mg/dl) & $<200$ desirable & $177 \pm 44.2$ & $172.5 \pm 42$ & $-4.5 \pm 23.7$ & 0.66 \\
\hline Triglycerides (mg/dl) & $<200$ desirable & $191.7 \pm 150.7$ & $192.5 \pm 108.2$ & $0.8 \pm 62.8$ & 0.97 \\
\hline LDL cholesterol (mg/dl) & $<100$ low risk & $99.5 \pm 34$ & $96 \pm 30.2$ & $-3.5 \pm 18.8$ & 0.67 \\
\hline HDL cholesterol (mg/dl) & $>55$ no risk & $39.2 \pm 11$ & $41.3 \pm 12.3$ & $2.2 \pm 9.8$ & 0.61 \\
\hline Dipstick proteinuria $^{\mathrm{a}}$ & Negative & $1.7 \pm 0.8$ & $1.3 \pm 0.5$ & $-0.3 \pm 1$ & 0.46 \\
\hline
\end{tabular}

ul microliter, $g / d l$ grams per deciliter, $H C T$ hematocrit, $M C V$ mean corpuscular volume, $f l$ femtoliters, FBS fasting blood sugar, $H b A 1 c$ hemoglobin A1c, mg/dl milligram per deciliter, $\mathrm{mEq} / \mathrm{l}$ milliequivalents per liter, TSH thyroid-stimulating hormone, $M I U / \mathrm{m} / \mathrm{milli}$-international units per milliliter, $P T H$ parathyroid hormone, $\mathrm{pg} / \mathrm{ml}$ pictogram per milliliter, ESR erythrocyte sedimentation rate, $\mathrm{mm} / \mathrm{h}$ millimeters per hour, CRP C-reactive protein, $\mathrm{mg} / \mathrm{l}$ milligram per liter, ALT alanine aminotransferase, U/lit units per liter, AST aspartate aminotransferase, LDL low-density lipoprotein, HDL high-density lipoprotein

a Negative or $1=0 \mathrm{mg} / \mathrm{dl} ; 2=15-30 \mathrm{mg} / \mathrm{dl} ; 3=30-100 \mathrm{mg} / \mathrm{dl} ; 4=100-300 \mathrm{mg} / \mathrm{d} ; 5=300-1000 \mathrm{mg} / \mathrm{dl} ; 6>1000 \mathrm{mg} / \mathrm{dl}$

polycystic kidney disease (ARPKD) model [13]. They also reported the safety of the MSC infusion with no mortality related to their protocol, which supported our safety results.

There is a growing body of clinical research which indicates that a systematic MSC infusion is safe under different conditions [24], including renal diseases [7, 9]. No AEs such as acute infusion toxicity, organ complications, infections, death or malignancies associated with systematic infusion of these cells have been reported in human studies [24]. In concordance with their results, our study showed the safety of an intravenous MSC infusion following comprehensive assessment of AEs, SAEs, and clinical and paraclinical parameters. There are also reports of potential efficacy and safety of MSC infusions in patients with different etiologies of CKD [9, 25-27]. However, there is a lack of data demonstrates the impact of MSCs on PKD.

ADPKD progression is associated with several pathways such as apoptosis [28], fibrosis [2, 29, 30], inflammation [2, 31, 32], cyst proliferation, renin-angiotensin system (RAS) activation [33, 34], and kidney vasculature impairment [13]. MSCs may affect these pathways through different mechanisms, as briefly discussed in the following.

Recent experimental studies reported that MSCs predominantly improved kidney tubular regeneration by secretion of growth factors, cytokines, and chemokines which decrease apoptosis, inflammation, and fibrosis [7], and subsequently ameliorate kidney function (creatinine clearance, eGFR, and HTN) and structure in CKD models [7, 9]. The potential capabilities of MSCs [35] are not limited to antifibrotic and anti-inflammatory effects on CKD models $[11,12]$ and its beneficial impact on apoptosis in an AKI model $[10,36]$ which could be useful for PKD.

Rapamycin decreases the proliferation of CD133+ and CD24+ cells and cyst formation in vitro through inhibition of the mechanistic target of rapamycin (mTOR) in PKD [17]. In our in vitro study, we observed that MSCs 
Table 4 Changes in renal function parameters and blood pressure (BP) from 1 year before mesenchymal stromal cell (MSC) infusion, baseline and the 12-month follow up

\begin{tabular}{|c|c|c|c|c|c|c|c|c|c|c|c|}
\hline Patient parameters & Normal range & -12 & Baseline & 12-month & $\begin{array}{l}P \text { value } \\
\text { (RMA) }\end{array}$ & $\begin{array}{l}\text { Dif } 1 \\
\text { (BV-1yp) }\end{array}$ & $\begin{array}{l}P \text { value } \\
\text { Dif } 1\end{array}$ & $\begin{array}{l}\text { Dif } 2 \\
(12 \text { m-BV) }\end{array}$ & $\begin{array}{l}P \text { value } \\
\text { Dif } 2\end{array}$ & $\begin{array}{l}\text { Dif } 3 \\
\text { (dif2- dif1) }\end{array}$ & $\begin{array}{l}P \text { valve } \\
\text { Dif } 3\end{array}$ \\
\hline $\mathrm{SBP}(\mathrm{mmHg})$ & $<120$ & $123.8 \pm 9.6$ & $125.2 \pm 10.3$ & $126.8 \pm 5.7$ & 0.55 & $1.3 \pm 6.8$ & 0.65 & $1.6 \pm 5.0$ & 0.46 & NA & NA \\
\hline $\mathrm{DBP}(\mathrm{mmHg})$ & $60-80$ & $77.7 \pm 3.5$ & $75.8 \pm 5.6$ & $78.8 \pm 3.3$ & 0.43 & $-1.8 \pm 4.5$ & 0.36 & $3 \pm 6$ & 0.27 & NA & NA \\
\hline BUN (mg/dl) & $7-20.6$ & $28.5 \pm 8.6$ & $27.8 \pm 10.5$ & $29.5 \pm 7.1$ & 0.92 & $-0.6 \pm 12.7$ & 0.90 & $1.7 \pm 4.3$ & 0.38 & NA & NA \\
\hline $\mathrm{SCr}(\mathrm{mg} / \mathrm{dl})$ & $0.4-1.4$ & $2 \pm 0.3$ & $2.5 \pm 0.4$ & $2.5 \pm 0.6$ & $0.02^{b}$ & $0.5 \pm 0.4$ & $0.04^{b}$ & $0 \pm 0.3$ & 0.96 & $0.5 \pm 0.5$ & $0.05^{b}$ \\
\hline eGFR ${ }^{a}$ & $90-120$ & $33.8 \pm 5.3$ & $26.7 \pm 3.1$ & $25.8 \pm 6.2$ & $0.01^{b}$ & $-7.2 \pm 6$ & $0.03^{b}$ & $-0.8 \pm 3.9$ & 0.62 & $-6.3 \pm 7.5$ & 0.09 \\
\hline Rt KL (cm) & $10-12$ & NA & $19.1 \pm 2$ & $19.5 \pm 2$ & NA & NA & NA & $0.4 \pm 0.6$ & 0.13 & NA & NA \\
\hline Lt KL (cm) & $10-12$ & NA & $18.3 \pm 2.4$ & $18.7 \pm 2.6$ & NA & NA & NA & $0.4 \pm 0.4$ & 0.06 & NA & NA \\
\hline
\end{tabular}

$B V$ baseline visit, 1 yp 1 year prior to intervention, $12 \mathrm{~m} 12$ month after baseline, $R M A$ repeated measures ANOVA, Dif difference, SPB systolic blood pressure, $m m H g$ millimeter of mercury, NA not applicable, DBP diastolic blood pressure, BUN blood urea nitrogen, $\mathrm{mg} / \mathrm{dl}$ milligram per deciliter $S C r$ serum creatinine, eGFR estimated glomerular filtration rate, $R t$ right, $K L$ kidney length, $L t$ left

aDRD study formula $\left(\mathrm{ml} / \mathrm{min} / 1.73 \mathrm{~m}^{2}\right)$

b Significant

could reduce the proliferative potential and cyst formation of CD133+ progenitor cells from ADPKD patients (unpublished data).

The mitogen-activated protein kinase (MAPK) family is involved in proliferation, apoptosis, and fibrosis in PKD. MSC-derived conditioned medium has been shown to inhibit p38 mitogen-activated protein kinases (p38) and extracellular signal-regulated kinase (ERK) activity (MAPK family) as well as induce antiapoptotic effects in an AKI rat model [37].

Various studies illustrated that downregulation of proinflammatory cytokines reduced cyst formation and inflammation in ADPKD [38-40]. MSCs have the potential to decrease both the activity of the nuclear factor kappa B (NF-kB) pathway [11] and pro-inflammatory cytokines, which eventually lessen inflammation in a CKD model [12].

Following ADPKD progression, renovascular architecture disrupts where there is the vessel network around the cyst [13, 41]. Vascular endothelial growth factor (VEGF) is an antiapoptotic molecule [42] that can normalize the blood vessel network surrounding the cysts, BUN, SCr, and the cyst disorder as well as reduce macrophage pericystic infiltration in an ARPKD model [43]. VEGF $C$ has been shown to decrease in an ARPKD mice model [43]. Human MSCs are a source of VEGF and may be useful for appropriate angiogenesis [44].

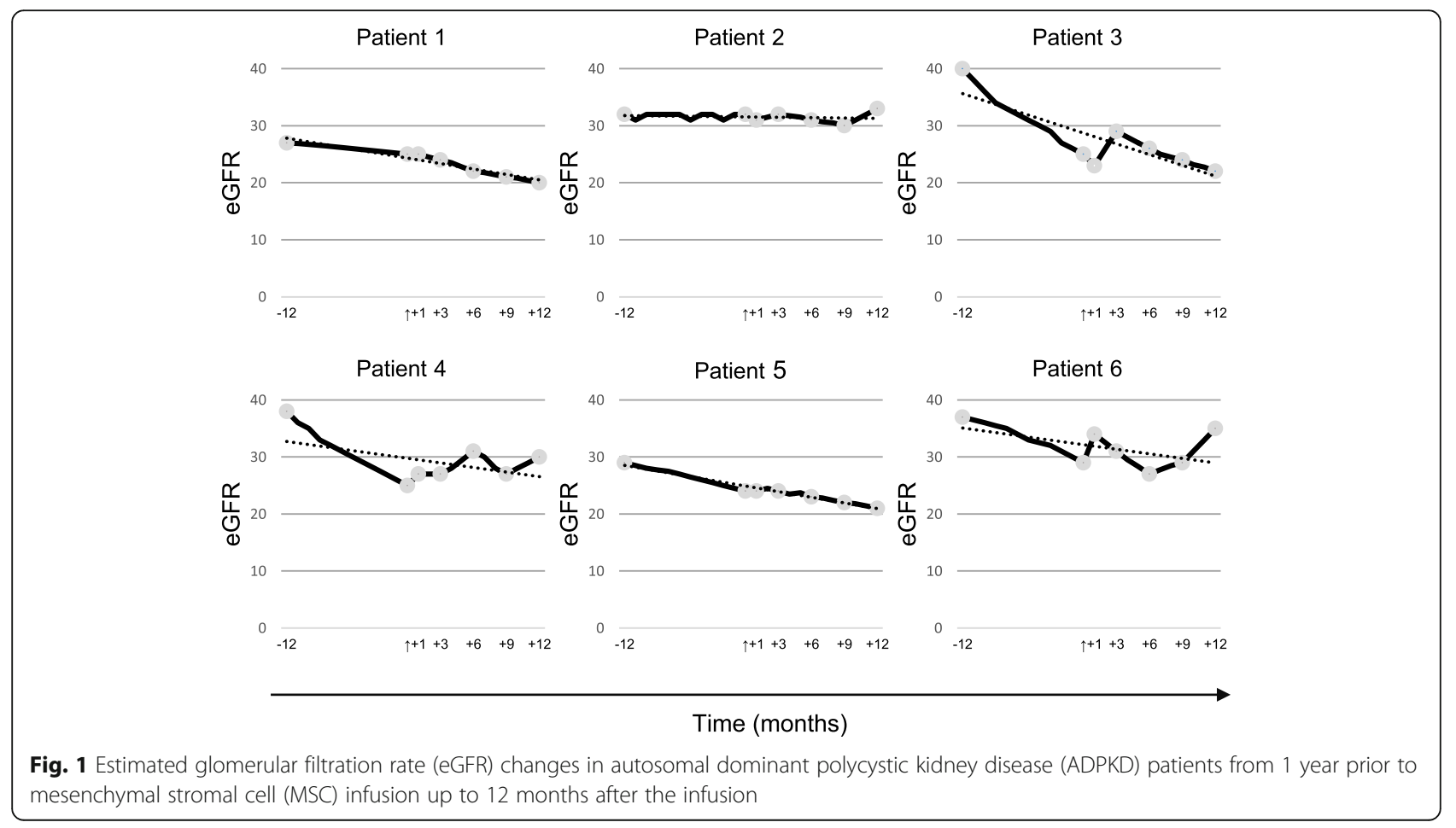


RAS inhibition improves BP and TKV, and prevents the spread of cyst formation in experimental animal models and humans [23, 45]. MSCs reduce renin, angiotensin-converting enzyme (ACE), and angiotensin II type 1 (AT1) receptor expression, and lead to reductions in BP, inflammation, and fibrosis [46, 47]. The MSC inhibitory effect on RAS is more stable than ACE inhibitors [47].

Taken together, following the safety and tolerability results of our study, the next step is to test the efficacy of MSC in ADPKD patients.

\section{Limitations}

The current trial limitations included our inability to demonstrate the efficacy due to the study design that consisted of a small sample size, lack of a control group, short follow-up period, the single cell infusion, and not using htTKV as a surrogate endpoint.

\section{Conclusions}

This trial demonstrated that an intravenous infusion of autologous MSCs was safe and well tolerated in ADPKD patients. We could not assess the efficacy due to the trial design. Our findings should be investigated in a randomized placebo-controlled trial with a larger population, which we intend to perform.

\section{Additional files}

Additional file 1: Table S1. Method of kidney ultrasound imaging. DTPA kidney scan method. Cell parameters for the study patients. Table S2. Safety assessment of the mesenchymal stromal cell (MSC) infusion in 1 year following baseline visit of study patients. Table S3. Laboratory parameters at baseline, 1, 3, 6, 9, and 12 months of follow-up. Table S4. Changes in renal function parameters and blood pressure (BP) 1 year before, and at 1, 3, 6, 9, and 12 months after mesenchymal stromal cell (MSC) infusion. (DOCX $70 \mathrm{~kb}$ )

Additional file 2: Figure S1. Characterization of the patients' bone mesenchymal stromal cells (MSCs). (DOCX $781 \mathrm{~kb}$ )

\footnotetext{
Abbreviations

ACE: Angiotensin-converting enzyme; ADPKD: Autosomal dominant polycystic kidney disease; ADPLD: Autosomal dominant polycystic liver disease; AE: Adverse events; AKI: Acute kidney injury; ARPKD: Autosomal recessive polycystic kidney disease; AT1: Angiotensin II receptor type 1; BM: Bone marrow; BMA: Bone marrow aspiration; BMMSCs: Bone marrow mesenchymal stromal cells; BP: Blood pressure; BUN: Blood urea nitrogen; CKD: Chronic kidney disease; CRISP: Consortium for Radiologic Imaging Studies of Polycystic Kidney Disease; CTCAE: Common Terminology Criteria for Adverse Events; DSMB: Data Safety Monitoring Board;

DTPA: Diethylenetriaminepentaacetic acid; eGFR: Estimated glomerular filtration rate; ERK: Extracellular signal-regulated kinase; ESRD: End-stage renal disease; FBS: Fetal bovine serum; FDO: Food and Drug Organization; FITC: Fluorescein isothiocyanate; GFR: Glomerular filtration rates; h: Hour; HLA: Human leukocyte antigen; HSC: Hematopoietic stem cell; HTN: Hypertension; htTKV: Height-adjusted total kidney volume; KL: Kidney length; LAL: Limulus amebocyte lysate; MAPK: Mitogen-activated protein kinase; MDRD: Modification of diet in renal disease; MRI: Magnetic resonance imaging; MSCs: Mesenchymal stromal cells; mTOR: Mechanistic target of rapamycin; NF-kB pathway: Nuclear factor kappa B - a prototypical proinflammatory signaling pathway; p38: p38 mitogen-activated protein kinases; PE: Phycoerythrin; PKD: Polycystic kidney disease; QCT: Quality control tests;
}

RAS: Renin-angiotensin system; SAE: Serious adverse events; SCr: Serum creatinine; SD: Standard deviation; Tregs: Regulatory T cells;

V2RA: Vasopressin II receptor antagonist; VEGF: Vascular endothelial growth factor; a-MEM: alpha modified Eagle medium

\section{Acknowledgments}

We gratefully express our appreciation to Ms. Dastvan for proofreading this article, Ms. Salimiyan for assistance with data gathering, Dr. Moininia for bone marrow aspiration, and Dr. Dastgheib, Dr. Ghasemi and Ms. Khoshdelrad for their valuable comments, in addition to Dr. Amini for assistance with statistical analyses. We are grateful to members of the Department of Regenerative Medicine for their expertise and feedback. We would particularly like to thank the patients and their families for participating in this study.

\section{Funding}

This trial was supported by a grant from Royan Institute and the Royan Charity Association for Health Research.

\section{Availability of data and materials}

The data that support the findings of this study are available from the enrolled patients but restrictions apply to the availability of these data, which were used under license for the current study. Hence, they are not publicly available. However, the data are available from the authors upon reasonable request and with permission of the enrolled patients.

\section{Authors' contributions}

AM, NA, and RM conceived and designed the original protocol. All authors were involved in amending the protocol. AM and SSH coordinated the study. $\mathrm{NJ}$ and TB performed the cell processing. AM, BE, and SSH were involved in patient recruitment and follow-up visits. Data entry was performed by SSH and SEH, and SSH performed the cell infusion. SSH cleaned and analyzed the data. $\mathrm{SSH}$ wrote the first draft of the manuscript. HB oversaw the manuscript preparation and revised the first draft. NA supervised the study. All authors contributed to subsequent and final drafts. All authors read and approved the final manuscript.

\section{Competing interests}

The authors declare that they have no competing interests.

\section{Consent for publication}

All patients gave written informed consent for publication.

\section{Ethics approval and consent to participate}

We conducted this study in accordance with the Declaration of Helsinki. The Institutional Review Board (IRB) and local Ethics Committee (Royan Research Ethics Committee, number: 91000316) approved this study. The DSMB and the trial monitor reviewed the entire trial to ensure participants' safety. All patients gave written informed consent for participation.

\section{Publisher's Note}

Springer Nature remains neutral with regard to jurisdictional claims in published maps and institutional affiliations.

\section{Author details \\ ${ }^{1}$ Department of Nephrology, Molecular and Cell Biology Research Center, Sari University of Medical Sciences, Sari, Iran. ${ }^{2}$ Department of Regenerative Biomedicine, Cell Science Research Center, Royan Institute for Stem Cell Biology and Technology, ACECR, Tehran, Iran. ${ }^{3}$ Department of Stem Cells and Developmental Biology, Cell Science Research Center, Royan Institute for Stem Cell Biology and Technology, ACECR Tehran, Iran. ${ }^{4}$ Nephrology and Urology Research Center, Baqiyatallah University of Medical Sciences, Baqiyatallah Hospital, Tehran, Iran.}

Received: 26 January 2017 Revised: 3 April 2017

Accepted: 6 April 2017 Published online: 23 May 2017

\section{References}

1. Iglesias CG, Torres VE, Offord KP, Holley KE, Beard CM, Kurland LT. Epidemiology of adult polycystic kidney disease, Olmsted County, Minnesota: 1935-1980. Am J Kidney Dis. 1983;2(6):630-9. 
2. Torra R. Autosomal dominant policystic kidney disease, more than a renal disease. Minerva Endocrinol. 2014;39(2):79-87.

3. Chang MY, Ong AC. New treatments for autosomal dominant polycystic kidney disease. Br J Clin Pharmacol. 2013;76(4):524-35.

4. Bastos AP, Onuchic LF. Molecular and cellular pathogenesis of autosomal dominant polycystic kidney disease. Braz J Med Biol Res. 2011;44(7):606-17.

5. Torres VE, Chapman AB, Devuyst O, Gansevoort RT, Grantham JJ, Higashihara E, Perrone RD, Krasa HB, Ouyang J, Czerwiec FS, et al. Tolvaptan in patients with autosomal dominant polycystic kidney disease. N Engl J Med. 2012;367(25):2407-18

6. Suzuki E, Fujita D, Takahashi M, Oba S, Nishimatsu H. Adult stem cells as a tool for kidney regeneration. World J Nephrol. 2016;5(1):43-52.

7. Morigi M, Rota C, Remuzzi G. Mesenchymal stem cells in kidney repair. Methods Mol Biol. 2016;1416:89-107.

8. Dominici M, Le Blanc K, Mueller I, Slaper-Cortenbach I, Marini F, Krause D, Deans R, Keating A, Prockop D, Horwitz E. Minimal criteria for defining multipotent mesenchymal stromal cells. The International Society for Cellular Therapy position statement. Cytotherapy. 2006;8(4):315-7.

9. Hickson LJ, Eirin A, Lerman LO. Challenges and opportunities for stem cell therapy in patients with chronic kidney disease. Kidney Int. 2016; 89(4):767-78.

10. Bruno S, Grange C, Collino F, Deregibus MC, Cantaluppi V, Biancone L, Tetta C, Camussi G. Microvesicles derived from mesenchymal stem cells enhance survival in a lethal model of acute kidney injury. PLoS One. 2012;7(3), e33115.

11. Wu HJ, Yiu WH, Li RX, Wong DW, Leung JC, Chan LY, Zhang Y, Lian Q, Lin M, Tse HF, et al. Mesenchymal stem cells modulate albumin-induced renal tubular inflammation and fibrosis. PLoS One. 2014;9(3), e90883.

12. Semedo P, Correa-Costa M, Antonio Cenedeze M, Maria Avancini Costa Malheiros D, Antonia dos Reis M, Shimizu MH, Seguro AC, Pacheco-Silva A, Saraiva Camara NO. Mesenchymal stem cells attenuate renal fibrosis through immune modulation and remodeling properties in a rat remnant kidney model. Stem Cells. 2009;27(12):3063-73.

13. Franchi F, Peterson KM, Xu R, Miller B, Psaltis PJ, Harris PC, Lerman LO, Rodriguez-Porcel M. Mesenchymal stromal cells improve renovascular function in polycystic kidney disease. Cell Transplant. 2015;24(9):1687-98.

14. Moghadasali R, Mutsaers HA, Azarnia M, Aghdami N, Baharvand H, Torensma R, Wilmer MJ, Masereeuw R. Mesenchymal stem cell-conditioned medium accelerates regeneration of human renal proximal tubule epithelial cells after gentamicin toxicity. Exp Toxicol Pathol. 2013;65(5):595-600.

15. Moghadasali R, Azarnia M, Hajinasrollah M, Arghani H, Nassiri SM, Molazem M, Vosough A, Mohitmafi S, Najarasl M, Ajdari Z, et al. Intra-renal arterial injection of autologous bone marrow mesenchymal stromal cells ameliorates cisplatin-induced acute kidney injury in a rhesus Macaque mulatta monkey model. Cytotherapy. 2014;16(6):734-49.

16. Moghadasali R, Hajinasrollah M, Argani H, Nassiri SM, Najarasl M, Sodeifi N, Baharvand H, Aghdami N. Autologous transplantation of mesenchymal stromal cells tends to prevent progress of interstitial fibrosis in a rhesus Macaca mulatta monkey model of chronic kidney disease. Cytotherapy. 2015;17(11):1495-505.

17. Carvalhosa R, Deambrosis I, Carrera P, Pasquino C, Rigo F, Ferrari M, Lasaponara F, Ranghino A, Biancone L, Segoloni G, et al. Cystogenic potential of CD133+ progenitor cells of human polycystic kidneys. J Pathol. 2011;225(1):129-41.

18. Pei $Y$, Obaji J, Dupuis A, Paterson AD, Magistroni R, Dicks E, Parfrey $P$, Cramer B, Coto E, Torra R, et al. Unified criteria for ultrasonographic diagnosis of ADPKD. J Am Soc Nephrol. 2009;20(1):205-12.

19. Hartung EA. Biomarkers and surrogate endpoints in kidney disease. Pediatr Nephrol. 2016;31(3):381-91.

20. Vlajkovic S, Cukuranovic R, Bjelakovic MD, llic G, Jaksic T, Cukuranovic J. Relative length of human kidney as more precise measuring of normal kidney. Med Pregl. 2010;63(11-12):784-7.

21. Bhutani H, Smith V, Rahbari-Oskoui F, Mittal A, Grantham JJ, Torres VE, Mrug M, Bae KT, Wu Z, Ge Y, et al. A comparison of ultrasound and magnetic resonance imaging shows that kidney length predicts chronic kidney disease in autosomal dominant polycystic kidney disease. Kidney Int. 2015;88(1):146-51.

22. Bae KT, Tao C, Wang J, Kaya D, Wu Z, Bae JT, Chapman AB, Torres VE, Grantham JJ, Mrug M, et al. Novel approach to estimate kidney and cyst volumes using mid-slice magnetic resonance images in polycystic kidney disease. Am J Nephrol. 2013;38(4):333-41.
23. Schrier RW. Blood pressure in early autosomal dominant polycystic kidney disease. N Engl J Med. 2015;372(10):976-7.

24. Lalu MM, McIntyre L, Pugliese C, Fergusson D, Winston BW, Marshall JC, Granton J, Stewart DJ. Canadian Critical Care Trials Group. Safety of cell therapy with mesenchymal stromal cells (SafeCell): a systematic review and meta-analysis of clinical trials. PLoS One. 2012;7(10), e47559.

25. Tan J, Wu W, Xu X, Liao L, Zheng F, Messinger S, Sun X, Chen J, Yang S, Cai J, et al. Induction therapy with autologous mesenchymal stem cells in living-related kidney transplants: a randomized controlled trial. JAMA. 2012;307(11):1169-77.

26. El-Ansary M, Saadi G, Abd El-Hamid SM. Mesenchymal stem cells are a rescue approach for recovery of deteriorating kidney function. Nephrology (Carlton). 2012;17(7):650-7.

27. Lee H, Park JB, Lee S, Baek S, Kim H, Kim SJ. Intra-osseous injection of donor mesenchymal stem cell (MSC) into the bone marrow in living donor kidney transplantation; a pilot study. J Transl Med. 2013;11:96.

28. Riella C, Czarnecki PG, Steinman TI. Therapeutic advances in the treatment of polycystic kidney disease. Nephron Clin Pract. 2014;128 (3-4):297-302.

29. Omori S, Hida M, Fujita H, Takahashi H, Tanimura S, Kohno M, Awazu M. Extracellular signal-regulated kinase inhibition slows disease progression in mice with polycystic kidney disease. J Am Soc Nephrol. 2006;17(6):1604-14.

30. Sugiyama N, Kohno M, Yokoyama T. Inhibition of the p38 MAPK pathway ameliorates renal fibrosis in an NPHP2 mouse model. Nephrol Dial Transplant. 2012;27(4):1351-8.

31. Nagao S, Yamaguchi T, Kusaka M, Maser RL, Takahashi H, Cowley BD, Grantham JJ. Renal activation of extracellular signal-regulated kinase in rats with autosomal-dominant polycystic kidney disease. Kidney Int. 2003;63(2):427-37.

32. Okumura Y, Sugiyama N, Tanimura S, Nishida M, Hamaoka K, Kohno M, Yokoyama T. ERK regulates renal cell proliferation and renal cyst expansion in inv mutant mice. Acta Histochem Cytochem. 2009;42(2):39-45.

33. Torres VE, Donovan KA, Scicli G, Holley KE, Thibodeau SN, Carretero OA, Inagami T, McAteer JA, Johnson CM. Synthesis of renin by tubulocystic epithelium in autosomal-dominant polycystic kidney disease. Kidney Int. 1992:42(2):364-73.

34. Saigusa T, Dang Y, Bunni MA, Amria MY, Steele SL, Fitzgibbon WR, Bell PD. Activation of the intrarenal renin-angiotensin-system in murine polycystic kidney disease. Physiol Rep. 2015;3(5), e12405.

35. Patel DM, Shah J, Srivastava AS. Therapeutic potential of mesenchymal stem cells in regenerative medicine. Stem Cells Int. 2013;2013:496218.

36. Zhou Y, Xu H, Xu W, Wang B, Wu H, Tao Y, Zhang B, Wang M, Mao F, Yan $Y$, et al. Exosomes released by human umbilical cord mesenchymal stem cells protect against cisplatin-induced renal oxidative stress and apoptosis in vivo and in vitro. Stem Cell Res Ther. 2013;4(2):34.

37. Qi S, Wu D. Bone marrow-derived mesenchymal stem cells protect against cisplatin-induced acute kidney injury in rats by inhibiting cell apoptosis. Int J Mol Med. 2013;32(6):1262-72.

38. Li X, Magenheimer BS, Xia S, Johnson T, Wallace DP, Calvet JP, Li R. A tumor necrosis factor-alpha-mediated pathway promoting autosomal dominant polycystic kidney disease. Nat Med. 2008;14(8):863-8.

39. Ta MH, Harris DC, Rangan GK. Role of interstitial inflammation in the pathogenesis of polycystic kidney disease. Nephrology (Carlton). 2013; 18(5):317-30

40. Lee EJ, Song SA, Mun HW, Yoo KH, Choi SY, Park EY, Park JH. Blockade of interleukin-8 receptor signalling inhibits cyst development in vitro, via suppression of cell proliferation in autosomal polycystic kidney disease. Nephrology (Carlton). 2014;19(8):471-8.

41. Xu R, Franchi F, Miller B, Crane JA, Peterson KM, Psaltis PJ, Harris PC, Lerman LO, Rodriguez-Porcel M. Polycystic kidneys have decreased vascular density: a micro-CT study. Microcirculation. 2013;20(2):183-9.

42. Ilic D, Almeida EA, Schlaepfer DD, Dazin P, Aizawa S, Damsky CH. Extracellular matrix survival signals transduced by focal adhesion kinase suppress p53-mediated apoptosis. J Cell Biol. 1998;143(2):547-60.

43. Huang JL, Woolf AS, Kolatsi-Joannou M, Baluk P, Sandford RN, Peters DJ, McDonald DM, Price KL, Winyard PJ, Long DA. Vascular endothelial growth factor C for polycystic kidney diseases. J Am Soc Nephrol. 2016; 27(1):69-77.

44. Kagiwada H, Yashiki T, Ohshima A, Tadokoro M, Nagaya N, Ohgushi H. Human mesenchymal stem cells as a stable source of VEGF-producing cells. J Tissue Eng Regen Med. 2008;2(4):184-9. 
45. Zafar I, Tao Y, Falk S, McFann K, Schrier RW, Edelstein CL. Effect of statin and angiotensin-converting enzyme inhibition on structural and hemodynamic alterations in autosomal dominant polycystic kidney disease model. Am J Physiol Renal Physiol. 2007;293(3):F854-9.

46. Oliveira-Sales EB, Maquigussa E, Semedo P, Pereira LG, Ferreira VM, Camara NO, Bergamaschi CT, Campos RR, Boim MA. Mesenchymal stem cells (MSC) prevented the progression of renovascular hypertension, improved renal function and architecture. PLoS One. 2013;8(11), e78464.

47. Gregorini M, Corradetti V, Rocca C, Pattonieri EF, Valsania T, Milanesi S, Serpieri $\mathrm{N}$, Bedino G, Esposito P, Libetta C, et al. Mesenchymal stromal cells prevent renal fibrosis in a rat model of unilateral ureteral obstruction by suppressing the renin-angiotensin system via HuR. PLoS One. 2016;11 (2), e0148542.

Submit your next manuscript to BioMed Central and we will help you at every step:

- We accept pre-submission inquiries

- Our selector tool helps you to find the most relevant journal

- We provide round the clock customer support

- Convenient online submission

- Thorough peer review

- Inclusion in PubMed and all major indexing services

- Maximum visibility for your research

Submit your manuscript at www.biomedcentral.com/submit
Biomed Central 